\title{
Intergenerational and Marriage Mobility of University Professors in the Netherlands During the 19th Century
}

By Ineke Maas, Marco H. D. van Leeuwen and Antonie Knigge

To cite this article: Maas, I., van Leeuwen, M. H. D. \& Knigge A. (2021). Intergenerational and Marriage Mobility of University Professors in the Netherlands During the 19th Century. Historical Life Course Studies, 10, 167-171. https://doi. org $/ 10.51964 /$ hlcs9588

\section{HISTORICAL LIFE COURSE STUDIES}

Not Like Everybody Else.

Essays in Honor of Kees Mandemakers

VOLUME 10, SPECIAL ISSUE 3

2021

GUEST EDITORS

Hilde Bras

Jan Kok

Richard L. Zijdeman 


\section{HISTORICAL LIFE COURSE STUDIES}

Historical Life Course Studies is the electronic journal of the European Historical Population Samples Network (EHPSNet). The journal is the primary publishing outlet for research involved in the conversion of existing European and nonEuropean large historical demographic databases into a common format, the Intermediate Data Structure, and for studies based on these databases. The journal publishes both methodological and substantive research articles.

\section{Methodological Articles}

This section includes methodological articles that describe all forms of data handling involving large historical databases, including extensive descriptions of new or existing databases, syntax, algorithms and extraction programs. Authors are encouraged to share their syntaxes, applications and other forms of software presented in their article, if pertinent, on the openjournals website.

\section{Research articles}

This section includes substantive articles reporting the results of comparative longitudinal studies that are demographic and historical in nature, and that are based on micro-data from large historical databases.

Historical Life Course Studies is a no-fee double-blind, peer-reviewed open-access journal supported by the European Science Foundation (ESF, http://www.esf.org), the Scientific Research Network of Historical Demography (FWO Flanders, http://www.historicaldemography.be) and the International Institute of Social History Amsterdam (IISH, http://socialhistory.org/). Manuscripts are reviewed by the editors, members of the editorial and scientific boards, and by external reviewers. All journal content is freely available on the internet at https://openjournals.nl/index.php/hlcs.

\section{Co-Editors-In-Chief:}

Paul Puschmann (Radboud University) \& Luciana Quaranta (Lund University)

hislives@kuleuven.be

The European Science Foundation (ESF) provides a platform for its Member Organisations to advance science and explore new directions for research at the European level. Established in 1974 as an independent non-governmental organisation, the ESF currently serves 78 Member Organisations across 30 countries. EHPS-Net is an ESF Research Networking Programme.

The European Historical Population Samples Network (EHPS-net) brings together scholars to create a common format for databases containing non-aggregated information on persons, families and households. The aim is to form an integrated and joint interface between many European and non-European databases to stimulate comparative research on the micro-level.

Visit: http://www.ehps-net.eu.
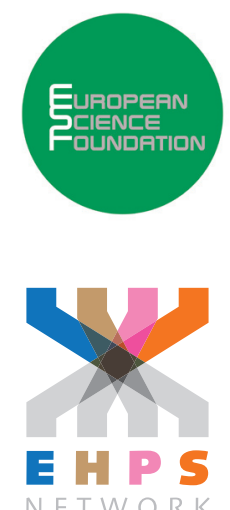


\title{
Intergenerational and Marriage Mobility of University Professors in the Netherlands During the 19th Century
}

\author{
Ineke Maas
}

Utrecht University \& VU Amsterdam

Marco H. D. van Leeuwen

Utrecht University

Antonie Knigge

Utrecht University

\begin{abstract}
In this study we ask the question to what extent 19 th-century university professors were a closed occupational group in the sense that they had little intergenerational and marriage mobility. We do so in honor of Kees Mandemakers, who is about to retire as a professor, but whose younger family members may follow in his footsteps. We derive competing hypotheses from cultural capital theory and the meritocracy thesis and test them using civil marriage records for the period 1813-1922 in six Dutch provinces ( $N=1,180,976$ marriages). Although only $4.4 \%$ of all university professors had a father in the same occupation, the odds ratio of 331 shows that this is much more likely than to be expected under independence. Similarly, professors were much more likely to marry the daughter of a professor. Compared to other elite occupations the intergenerational immobility of professors was not especially high, but their marriage immobility was exceptional. Cultural capital theory receives more support than the meritocracy thesis. We hope that Mandemakers, Mandemakers and Mandemakers will accept the challenge and investigate whether these findings can be generalized to contemporary society.
\end{abstract}

Keywords: Intergenerational mobility, Marriage mobility, Homogamy, Elites, Cultural capital theory, Meritocracy thesis

e-ISSN: $\quad 2352-6343$

DOI article: $\quad$ https://doi.org/10.51964/hlcs9588

The article can be downloaded from here.

(C) 2021, Maas, van Leeuwen, Knigge

This open-access work is licensed under a Creative Commons Attribution 4.0 International License, which permits use, reproduction \& distribution in any medium for non-commercial purposes, provided the original author(s) and source are given credit. See http://creativecommons.org/licenses/. 


\section{INTRODUCTION}

Whereas Kees Mandemakers is about to retire as a professor, his son Jornt and his nephew Luuk have just joined the faculty. It may make people wonder whether this is pure coincidence, or whether it was helpful for Jornt's (or Luuk's) academic career that his father (or uncle) was a professor? Answering this question for this particular case is not only next to impossible, it is also hardly relevant from a scientific point of view. It does relate, however, to an important topic in the stratification literature, namely whether occupations are relatively open to outsiders or closed off by being reserved for incumbents and their relatives. Most people desire an open and meritocratic society where occupational attainment depends on achieved characteristics such as talent and hard work, and not on ascriptive factors such as the family one is born into.

An important contribution of Kees Mandemakers' work is to help show that the Netherlands in the 19th and early 20th century was far from such an open society. Intergenerational mobility was much lower than it is nowadays: many sons had an occupation of similar standing as their father's (Knigge, Maas, van Leeuwen, \& Mandemakers, 2014). Likewise, there was relatively little marriage mobility as many people married a partner from within the same social layer (van Leeuwen, Maas, \& Mandemakers, 2005).

However, it is unknown whether professors were an exception to or an exemplification of these patterns. On the one hand, universities can be thought of as progressive places where meritocratic principles are especially valued and only the brightest can become professor. On the other hand, a university is also thought to require a lot of cultural capital and one's cultural capital depends largely on socialization during childhood. We therefore ask the question: To what extent were university professors a closed occupational group in the sense that they had little intergenerational and marriage mobility?

We will derive competing hypotheses from cultural capital theory and the meritocracy thesis. These hypotheses will be tested using data from Genlias, which in the present shape is a co-creation of Kees Mandemakers and others. We only study men because the first occurrence of a woman becoming university professor in the Netherlands happened as late as 1917 (Johanna Westerdijk).

Kees Mandemakers has been an icon of the Historical Sample of the Netherlands and similar datasets such as WieWasWie/GENLIAS (see e.g. Mandemakers, 2013, 2014, and iisg.amsterdam/hsn). We have had the pleasure both of profiting from these data and collaborating with him in writing articles (e.g. Knigge et al., 2014; van Leeuwen et al., 2005; Mandemakers, Maas, \& van Leeuwen, 2009) as well as coding occupations (Mandemakers et al., 2013), Mandemakers has also ventured in an important historical domain that has not had many visitors in recent times: the historical sociology of education (Mandemakers, 1996; Zijdeman \& Mandemakers, 2008).

\section{THEORY}

\subsection{CULTURAL CAPITAL THEORY}

Becoming a university professor required a lot of cultural capital. To begin, cultural capital was needed to enter secondary education, which was a rare event during this period (Mandemakers, 1996). And then more cultural capital was needed to successfully finish secondary education and university. Finally, the university itself is a bastion of cultural capital. In order to fit in and have a successful career one needs to know what to talk about, and how to behave (Bourdieu \& Passeron, 1990). Because cultural capital is so important at the university, university professors will also appreciate if their children marry someone who also possesses a lot of cultural capital. Therefore, they might bring their daughters in contact with their (younger) colleagues and they might introduce their sons to colleagues with daughters in a marriageable age. Based on this reasoning one would expect the following:

Hypothesis 1. University professors more often have a university professor as a father/father-in-law than one would expect on the basis of the assumption of independence.

Hypothesis 2. University professors more often have a university professor as a father/father-in-law than people with other 'elite' occupations have a father/father-in-law with the same occupation. 


\subsection{MERITOCRACY THESIS}

Becoming a university professor requires talent and knowledge that cannot easily be transferred from one generation to the other. Parents can help their children only to a certain extent. They can help them enter secondary education or university, but in order to become a professor they need to excel in school. That is something that even university professors cannot guarantee for their children. Moreover, for people in other elite occupations that depend less on talent and more on the possession of economic or social resources, it is easier to transfer their occupation to their son. If men become university professors because of their own talent and perseverance, they will probably also independently choose a marriage partner that has talents of her own.

Hypothesis 3. University professors do not more often have a university professor as a father/father-in-law than one would expect on the basis of independence.

Hypothesis 4. University professors less often have a university professor as a father/father-in-law than people with other 'elite' occupations have a father/father-in-law with the same occupation.

We use data from civil marriage records for the period 1813-1922 in six Dutch provinces: Groningen, Drenthe, Overijssel, Gelderland, Zeeland, and Limburg ( $N=1,180,976$ marriages). All occupations were coded into HISCO (van Leeuwen, Maas, \& Miles, 2002). Professors have HISCO-codes from 13100 to 13190. We distinguish the following other elite occupations: Mayors and other legislative officials (20110), General managers (21110), Officers in the army (58320), Engineers (02000-02990), Physicians (06105), Jurists (12110-12410), and Clergymen (14120). Table 1 shows the frequencies of these occupations in the data.

Table $1 \quad$ Frequencies of certain elite occupations in the data

\begin{tabular}{lrrr}
\hline & Groom & Father & Father-in-law \\
\hline University professor & 94 & 106 & 106 \\
Mayor & 885 & 1,261 & 1,715 \\
General manager & 4,396 & 2,334 & 2,380 \\
Officer & 2,454 & 401 & 567 \\
Engineer & 1,642 & 526 & 454 \\
Physician & 2,326 & 1,013 & 1,054 \\
Jurist & 2,100 & 914 & 1,114 \\
Clergyman & 2,292 & 1,717 & 1,629 \\
\hline
\end{tabular}

Note that there are very few missing values on groom's occupation (4.9\%), but almost half the occupations of the father and father-in-law are unknown (respectively $48.5 \%$ and $43.0 \%$ ), which is not unusual at all for historical datasets and is mainly due to the fact that fathers might have been deceased, or absent for other reasons, at the wedding of their child. Keeping this in mind, it becomes clear that men become university professors relatively late in their occupational careers, which is also true for mayors and clergymen $(2 * \mathrm{~N}$ father $>\mathrm{N}$ groom). General managers, physicians and jurists are found in equal numbers in all age groups $(2 * \mathrm{~N}$ father $\approx \mathrm{N}$ groom) and the other elite occupations (Officer and Engineer) are more often performed at a young age.

Because the occupations differ in the number of incumbents and there also unequal numbers of grooms and fathers/fathers-in-law, we will present odds ratios to indicate the amount of immobility. The odds ratios relate to a two-by-two crosstabulation of the elite occupation versus all other occupations (excluding missing values). We also present inflow percentages. They show the likelihood that if you would have met someone with this specific occupation this person's father (or father-in-law) would have the same occupation. 


\section{RESULTS}

If one would have been able to meet a university professor in the six Dutch provinces that we study during the 19th century, the likelihood that the father of this university professor would have appeared to be a university professor too would have been rather low: only $4.4 \%$. However, if one considers that the number of university professors was really low, this is far more than one would expect if there was no association between occupation of father and son. The odds ratio is 331.4, which means that the odds that university professors have a father with the same occupation are (331.4-1)*100 $=33,040 \%$ higher than the odds that they have a father with a different occupation.

If one would meet the same professor and ask him about his father-in-law, he would in truth answer with a likelihood of $16.3 \%$ that his father-in-law is also a university professor. The accompanying odds ratio is enormously high: 1,588.4. It is clear that hypothesis 1 is supported and hypothesis 3 is not. 19th century university professors did not reach their position based on talent alone. Some form of capital was transferred from father to son making it more likely that the son reached the same position as the father. And some form of capital also made it more likely that the university professor married the daughter of a (elderly) colleague.

Table 2 Occupational intergenerational and marital immobility of elite occupations

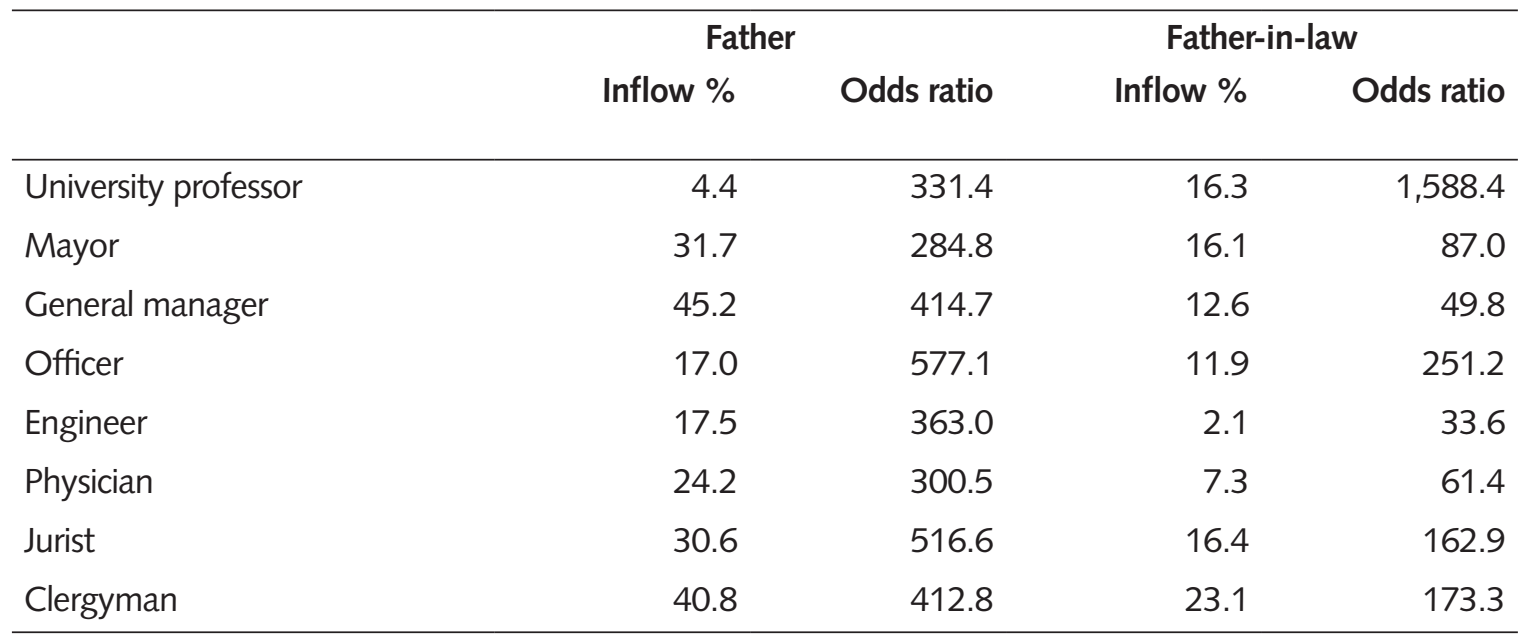

Notes: The inflow immobility \% is the percentage of sons that have a father/father-in-law with the same occupation. All odds ratios are significant $(p<0.001)$.

When we compare the odds ratio's for university professors with those for other elite occupations, we find that intergenerational immobility is not especially high for university professors. They are at the lower end of the scale followed by mayors, physicians, and engineers. The intergenerational immobility is highest for army officers, followed by jurists.

The order is rather different if we look at marital mobility. The immobility of university professors is six times that of the second highest group (the officers) and 47 times that of the engineers who have the lowest marital immobility. Our hypothesis 2 stating that immobility is higher for university professors than for other elite occupations is thus confirmed with respect to marital mobility, but not with respect to intergenerational mobility.

\section{DISCUSSION}

In this contribution, we showed that professor was a rather closed occupation in the Netherlands in the 19th century: professors were much more likely to have followed in the footsteps of their fathers and fathersin-law than would be expected by mere chance. With this, professors certainly did not form a positive exception compared to other elite occupations. Whereas the intergenerational immobility of professors was comparable, marital immobility was much larger than for other elite occupations. 
These observations are in line with cultural capital theory. If it was indeed the case that professor as an occupation was closed off to those without the appropriate cultural capital, it would mean that university hiring was not based on merit. However, in their own defense, a professor with a professor as a father or an uncle might point out that talents are transmitted from parent to child through genes (Tropf, Barban, Mills, Snieder, \& Mandemakers, 2015). This could also explain why sons of professors have such a high chance of becoming professors themselves. Moreover, the high marriage immobility of university professors is not necessarily a sign of nepotism either. Especially scholars fully devoted to work may only meet other university people (and through them their family). In other words, the opportunity structure of the marriage market could also produce the observed patterns.

An interesting follow-up study would be to see how our findings compare to intergenerational and marriage mobility of professors in contemporary Dutch society. To prevent boredom after retirement, we can imagine that Kees might take up this task, perhaps together with his son Jornt and nephew Luuk. We believe Mandemakers, Mandemakers \& Mandemakers would certainly be a group of good men for the job, although admittedly too few good men to top the study by Goodman, Goodman, Goodman \& Goodman (2015).

\section{REFERENCES}

Bourdieu, P., \& Passeron, J.-C. (1990). Reproduction in education, society and culture (2nd ed.). London: Sage Publications.

Goodman, A. C., Goodman, J., Goodman, L., \& Goodman, S. (2015). A few Goodmen: Surname-sharing economist coauthors. Economic Inquiry, 53, pp. 1392-1395. doi: 10.1111/ecin.12167

Knigge, A., Maas, I., van Leeuwen, M. H. D., \& Mandemakers, K. (2014). Status attainment of siblings during modernization. American Sociological Review, 79(3), pp.549-574. doi:10.1177/0003122414529586

Mandemakers, C. A. (1996). Gymnasiaal en middelbaar onderwijs: Ontwikkeling, structuur, sociale achtergrond en schoolprestaties, Nederland, ca. 1800-1986. Amsterdam: Stichting Beheer IISG.

Mandemakers, K. (2013). Historical Sample of the Netherlands (HSN). Dataset Linking Historical Lives (LHL), release 2013.01 [Data set]. International Institute of Social History.

Mandemakers, K. (2014). WieWasWie Marriage Certificates Firstnames (original values), release 2014_01 [Data set]. International Institute of Social History.

Mandemakers, K., Maas, I., \& van Leeuwen, M. H. D. (Eds.). (2009). Honderdvijftig jaar levenslopen. De Historische Steekproef Nederlandse bevolking (pp. 9-14). Amsterdam: Amsterdam University Press.

Mandemakers, K., Muurling, S., Maas, I., Van de Putte, B., Zijdeman, R. L., Lambert, P. S., van Leeuwen, M. H. D., van Poppel, F. W. A., \& Miles, A. (2013). HSN standardized, HISCO-coded and classified occupational titles, release 2013.01 [Data set]. International Institute of Social History.

Tropf, F. C., Barban, N., Mills, M. C, Snieder, H., \& Mandemakers, J. J. (2015). Genetic influence on age at first birth of female twins born in the UK, 1919-68, Population Studies, 69(2), pp. 129-145. doi: 10.1080/00324728.2015.1056823

van Leeuwen, M. H. D., Maas, I., \& Mandemakers, K. (2005). Het kiezen van een huwelijkspartner in Nederland 1840-1940: De rol van de familie. In J. Kok \& M. H. D. van Leeuwen (Eds.), Genegenheid en gelegenheid. Twee eeuwen partnerkeuze en huwelijk. Amsterdam: Aksant.

van Leeuwen, M. H. D., Maas, I., \& Miles, A. (2002). HISCO: Historical International Standard Classification of Occupations. Leuven: Leuven University Press.

Zijdeman, R. L., \& Mandemakers, K. (2008). De rol van het gymnasiaal en middelbaar onderwijs bij de intergenerationele overdracht van status, Nederland 1865-1940. In I. Maas, M. H. D. van Leeuwen \& K. Mandemakers (Eds.), Honderdvifttig jaar levenslopen. De Historische Steekproef Nederlandse bevolking (pp. 149-172). Amsterdam: Amsterdam University Press. 